\title{
Vernuwing in Historiese Jesus-Navorsing ${ }^{1}$
}

P F Craffert

(Unisa)

\section{ABSTRACT}

\section{Progress in historical Jesus research}

The approaches of the Jesus Seminar and the Third Quest to the study of the historical Jesus are compared. Three different aspects are considered: Why is it done?; What is it about? and How is it done? Despite differences, it is shown that on a philosophical and world-view level, they share a similar positivistic historiography and modernist worldview. The main distinction is that theTthird Questers supplement the latter with a supernatural element. Further, it is argued that progress in historical Jesus research cannot be achieved by providing new answers to old questions or by means of mere adjustments to any of these approaches. What is needed is an approach that asks different questions and goes in totally new directions. The outlines of such an approach is sketched.

\section{INLEIDING}

Aansprake van "vernuwing" in historiese Jesus navorsing is algemeen. Die rede hiervoor is te vinde in die wese van hierdie navorsingsveld: dit bestaan uit soveel komponente wat in honderde moontlike konfigurasies ingespan kan word, dat elke navorser wat 'n enkele of sommige hiervan wysig, aanspraak maak op vernuwing. Die uitdrukking "vernuwing in historiese Jesus navorsing" word in hierdie studie egter gebruik as aanduiding van ' $n$ alternatiewe benadering: dit bied nie bloot ander of nuwer antwoorde op bestaande vrae nie, maar vra ander vrae.

Die struktuur van die argument is redelik eenvoudig: wat in historiese Jesus navorsing gedoen word en hoe dit gedoen word, is direk afhanklik van waarom dit gedoen word. Met ander woorde, die redes waarom historiese Jesus navorsing aangepak word (byvoorbeeld, oor die aard van die berigte of die verhouding tussen die bronne) sowel as die metodes wat gebruik word, word bepaal deur die rede waarom dit gedoen word. Vernuwing, in hierdie studie, beteken daarom nie slegs 'n verandering aan sommige van die onderlinge komponente nie, maar van

\footnotetext{
Navorsing vir hierdie artikel is die gevolg van 'n Alexander von Humboldt 'Stipendiat' in Heidleberg, Duitsland.
} 
die rigting en aard van die ondersoek. Dit beteken nie dat bloot nuwe antwoorde op ou vrae gegee word nie, maar dat ander vrae gevra word. Om die argument te begryp, is dit nodig om aan te dui wat huidiglik in historiese Jesus navorsing gebeur en hoedat die wat, hoe en waarom vrae met mekaar verweefd is. Dit sal gedoen word deur eerstens kortliks te kyk na die temas waaroor historiese Jesus navorsing handel en tweedens die redes waarom dit gedoen word. Daarna sal enkele lyne oor hoe dit gedoen word, aangedui word. Dit is vanuit hierdie agtergrond dat oor vernuwing as 'n verandering van die rigting van navorsing en die stel van nuwe vrae, enkele opmerkings gemaak sal word.

\section{WAAROOR HANDEL HISTORIESE JESUS NAVORSING?}

Daar is geen homogene of eenvormige tradisie van historiese Jesus navorsing nie. Om die waarheid te sê, dit is belangrik om te besef dat daar nie so iets soos "dié vraag na die historiese Jesus" is nie, want navorsers gee nie maar net verskillende antwoorde op dieselfde vraag nie. Dit is veel meer kompleks, want nie alleen is daar verskille oor wat die vraagstuk(ke) is nie, maar ook oor watter benadering gevolg moet word in die beantwoording van die verskillende vrae. Om die prentjie nog verder te kompliseer, nie alle benaderinge vra dieselfde vrae of heg dieselfde waarde aan die verskillende vrae nie. Daar is nie eens eenstemmigheid waarom die vraag na Jesus as historiese figuur gevra moet word nie. Afhangend van die spesifieke benadering, val die klem waarom dit gedoen moet word en waaroor dit handel, op verskillende plekke.

Dit is daarom meer korrek om na "historiese Jesus navorsing" as 'n kompleks van probleme of vrae te verwys. Hier sal vier van die belangrikste komponente van hierdie kompleks bespreek word. Dit sal ook duidelik word dat elk van hierdie komponente op 'n eie en unieke manier deur die verskillende benaderinge (sien onder) hanteer word. Wat wel belangrik is, is dat elk van hierdie komponente een of ander rol speel in enige (historiese) voorstelling van Jesus. Daarom die vraag: Waaroor handel historiese Jesus navorsing?

\subsection{Oor Jesus se biografie}

Die meeste studies bevat óf uitgebreide argumente oor die verskillende aspekte van Jesus se biografie (sien byvoorbeeld Theissen en Merz 1998:151-184), of kort opsommings oor daardie aspekte wat algemeen aanvaar word (sien byvoorbeeld Sanders 1993:10-14). Hieronder val aspekte van Jesus se lewe in terme van kronologie (byvoorbeeld, wanneer hy gebore is en wanneer hy gesterf het of hoe lank die tydperk van sy openbare optrede was), van geografie (soos, ten opsigte van die plek van sy geboorte of die areas van sy openbare optrede) en voorstel- lings van gebeure in die evangelies (soos die vertelling oor die tempelreiniging of die proses van Jesus se verhoor).

Aspekte van sy biografie word gewoonlik hanteer onafhanklik van die ander vrae (soos wat hy sou, of nie sou gesê het nie). Een voorbeeld sal voldoende wees om aan te toon hoe hierdie aspek in die navorsing hanteer word.

Die geboorteverhale van beide Lukas en Matteus gee Betlehem aan as geboorteplek van Jesus. Kan dit as historiese feit aanvaar word, of is 'n alternatief moontlik?

Argumente teen Bethlehem as geboorteplek is van twee soorte. Aan die een kant word daarop gewys dat al die bronne deurgaans aanvaar en eksplisiet na Nasaret verwys as Jesus se tuisdorp. Aan die ander kant is die teologiese motief dat die Messias in die stad van Dawid gebore moet word baie duidelik te sien in die verhale. Hiermee is nie eens al die onoplosbare verskille tussen Matteus en Lukas betrek of die histories onwaarskynlike elemente in die verhale (soos om na jou tuisdorp te gaan vir 'n sensus) genoem nie. Om hierdie redes is geleerdes oor die hele spektrum dit eens dat Jesus slegs binne die raamwerk van heilsgeskiedenis (of as teologiese bevestiging) in Bethlehem gebore is (sien Sanders 1993:85-86; Crossan 1994:18-21; Theissen en Merz 1998:164-165). Met ander woorde, dat Bethlehem nie sy eintlike plek van geboorte was nie. $\mathrm{Nie}$ al hierdie navorsers is egter ewe gewillig om Nasaret as geboorteplek te identifiseer nie - sommiges reken wel dat sekerheid in die verband nie moontlik is nie (sien bv Meier 1991:215-216).

Die belangrike punt om raak te sien is dat hierdie soort historiografie uitgaan van die vraag watter biografiese gegewens in die bronne met vertroue aan Jesus toegeskryf kan word. Met ander woorde, kan dit wat direk gesê word as histories betroubare biografiese gegewens beskou word. Hierdie patroon kenmerk die meeste van die studies oor die biografiese komponente.

Hierdie was waarskynlik vir ' $n$ lang tyd die dominante vraag in die Afrikaanse wêreld na Jesus as historiese persoon: watter een van die evangelies is reg? Mens dink onwillekeurig aan die publikasie van Du Plessis, Nasaret of Egipte: Wie is reg? wat aanspraak maak om oor die historiese Jesus vraagstuk te handel, maar dan uitsluitlik handel oor wat hier genoem word biografiese aspekte.

\subsection{Oor wat Jesus sou gesê het}

'n Tweede (en belangrike) komponent in historiese Jesus navorsing het te doen met die vraag of die woorde wat in die evangelies aan Jesus toegeskryf word, wel van hom af kom. Die probleem dat hy waarskynlik in Aramees gepraat het en dat die bronne almal in Grieks geskryf is, skep natuurlik die probleem dat die woorde soos dit daar staan, nie deur Jesus

ISSN 1609-9982 = VERBUM ET ECCLESIA Jrg 22 (1) 2001 
gesê kon gewees het nie (sien Casey 1998:103; Funk 1996:79 wil egter argumenteer dat Jesus sommige dinge wel in Grieks gesê het). Dit vir 'n oomblik daar gelaat, bly die vraag in twee vorme bestaan. Kan spesifieke woorde aan Jesus toegeskryf word, en kan spesifieke soort uitsprake aan hom toegedig word? Die twee aspekte word kortliks bekyk.

Die eerste is of spesifieke woorde aan Jesus toegeskryf kan word. Het Jesus byvoorbeeld per geleentheid gesê dat sy omstanders nog sal lewe wanneer die wederkoms sal plaasvind (sien Mark 9:1, 13:30; Matt 10:23)? Indien wel, wat maak mens met die uitspraak wat sê dat selfs die Seun die tyd nie ken nie (wat op sy beurt weer in kontras is met Johannes wat dit duidelik maak dat Jesus wel alles geweet het). Wat van die woorde uit Psalm 22:1 wat volgens die kruisigingsverhale deur Jesus uitgespreek is? Was dit teologisering of werklike woorde?

Die tweede is of spesifieke soort uitsprake aan hom toegeskryf kan word. Veral op die punt van die eskatologie is daar vandag 'n hewige debat hangend: het Jesus self oor die eindtyd gepraat of is dit iets wat sy volgelinge opgemaak het (sien Funk 1996:145)? Was die verwagting van Jesus se terugkeer reeds deel van Jesus se prediking of ontstaan dit na en as gevolg van pase (sien die bespreking in Borg 1994:74-80). Deur bloot na die evangelie gegewens te kyk, is daar geen eenvoudige antwoord op die vraag nie, want uitsprake oor beide 'n eindverwagting en kritiek daarteen word in Jesus se mond gelê.

Dit behoort ten minste duidelik te wees dat indien sekere van die sentrale uitsprake of soorte uitsprake wat aan Jesus toegeskryf word, nie uit sy mond gekom het nie, dit verreikende implikasies inhou vir 'n beeld van hom as historiese figuur.

\subsection{Oor wat Jesus sou gedoen het}

'n Derde komponent van historiese Jesus navorsing handel oor die dinge wat Jesus sou gedoen het. Weereens kan ten minste twee soorte vrae hier geïdentifiseer word. Watter van die spesifieke dade wat aan Jesus toegeskryf word, het of kon hy wel uitgevoer het, en tweedens, watter van die dade wat aan hom toegeskryf word, is histories moontlik. Dit is weereens die aard en wese van die bronne self wat bydra tot hierdie probleem.

Die eerste vraag handel oor daardie dade waaroor die bronne verskil of waaroor die detail onvoldoende is om te besluit of dit histories moontlik was. Die tweede kategorie handel veral oor die wonders en genesings. Het en kon Jesus mense genees, kon hy op die see loop, en kon hy inderdaad voedsel vermenigvuldig sodat duisende mense gevoed kon word?

Hierdie is die soort vrae wat in historiese Jesus navorsing leef.

\subsection{Oor watse soort figuur Jesus as historiese persoon was}

' $n$ Vierde komponent in hierdie navorsing handel oor die breër prentjie. Watse soort persoon was Jesus? Was hy primêr 'n eskatologiese profeet of 'n wysheidsleraar, was hy primêr ' $n$ wonderwerker of 'n geneser, was hy dalk eerder 'n politieke en sosiale revolusionêr of 'n charismatiese heilige? Elkeen van hierdie beskrywings, en nog veel, veel meer verteenwoordig die konklusie van studies oor Jesus as historiese persoon.

In baie gevalle is hierdie beskrywings die finale etiket oor wie Jesus nou eintlik was wanneer slegs na die "outentieke material" gekyk is. In ander gevalle funksioneer dit as hipotese in die proses om te bepaal watter tradisies oor Jesus outentiek is of nie. So is Jesus meestal een of ander soort leraar in daardie studies wat begin met Jesus woorde as die outentieke laag van die tradisie (sien byvoorbeeld Funk 1996; Crossan 1991b), en is hy 'n eskatologiese profeet vir diegene wat sy profetiese optrede en woorde as outentieke kern neem (byvoorbeeld Sanders 1985). Vir iemand soos Wright (sien 1999b:22-23) is Jesus se sosiale tipe 'n beginpunt in sy hipotese oor wat outentieke materiaal is.

Hierdie komponent is van wesenlike belang in historiese Jesus navorsing omdat dit bepalend is vir die verstaan van talle ander komponente in die navorsing. Watse soort figuur Jesus was (leraar of profeet of towenaar, ensovoorts) speel 'n belangrike rol in die bepaling van die ander komponente.

\subsection{Samevatting}

Hierdie oorsig gee bloot ' $n$ aanduiding van die komponente waaroor historiese Jesus navorsing handel. Dit wil nie sê dat die elemente almal legitiem is, korrek hanteer word of hoegenaamd sentraal behoort te wees in die navorsing nie. Wat dit wel aandui, is dat dit op een of ander manier in hierdie navorsingsveld hanteer word. Om beter perspektief daarop te kry, kan vervolgens gekyk word na waarom historiese Jesus navorsing nodig is.

\section{WAAROM IS HISTORIESE JESUS NAVORSING NODIG?}

Hierdie vraag kan op twee verskillende maniere verstaan word. Dit kan verstaan word as die vraag: Wat kan met historiese Jesus navorsing gemaak word? Is dit byvoorbeeld noodsaaklik vir goeie teologiese refleksie of vir die versterking van geloof. Hierdie is 'n debat op sy eie en gaan nie hier aangespreek word nie.

Hier word die vraag anders gestel: "Wat is daar in die bronne en in die voorstellings van Jesus wat historiese navorsing noodsaak? Waarom is dit 'n probleem om iets oor Jesus as historiese persoon te weet? Watse soort persoon was Jesus van Nasaret voor sy dood en wat het hy waar- 
skynlik gesê en gedoen in sy lewe? Kan die evangelies nie maar op sigwaarde geneem word vir wat hulle aanbied nie?"

Oor Jesus van Nasaret is daar meer bronne beskikbaar as oor die meeste ander antieke historiese figure. Waarom is dit dan steeds 'n probleem om Jesus as historiese figuur te verstaan? Anders gestel, dit is nie altyd voor die hand liggend waarom 'n historiese studie van Jesus noodsaaklik is, of waarom dit ' $n$ probleem is om bogenoemde vrae te beantwoord nie. Ten minste die volgende drie redes kan genoem word waarom historiese Jesus navorsing in hierdie sin nodig is.

\subsection{Die verskille tussen die bronne noodsaak die vraag}

Op 'n verskeidenheid maniere, oordeel die navorsing, is die verskille tussen die bronne verantwoordelik vir die probleme om Jesus as historiese figuur te verstaan of om sekere aspekte van sy doen en late vas te stel (sien Theissen \& Merz 1998 vir voorbeelde). Aan die een kant is daar die verskille tussen die sinoptiese evangelies en Johannesevangelie, en aan die ander kant die verskille tussen al die bronne onderling. ' $n$ Voorbeeld van die eerste is die voorstelling van Markus dat Jesus se Messiasskap tydens sy aardse optrede 'n geheim was, en Johannes se voorstelling dat Jesus dikwels tydens sy aardse optrede oor sy identiteit en doel gepraat het. Jesus kon nie sy optrede in geheimhouding gevoer het (soos Markus sê), en dit terselfdertyd verkondig het, (soos Johannes sê) nie. Een, of beide, van hierdie voorstellings strook nie met die werklikheid nie.

Die verskille tussen die bronne onderling is byna onoorskoulik, want hulle verskil op haas elke punt. Jesus se geslagsregister kon nie tegelyk soos Matteus s'n en soos Lukas s'n gelyk het nie. Indien aanvaar word dat een korrekte historiese inligting verskaf, is die vraag watter een, en is die ander een dan verkeerd? As aanvaar word dat beide dit bloot gebruik het vir teologiese motiewe ( $\mathrm{m}$ a w geen korrekte weergawe van Jesus se werklike geslagsregister is gegee nie), is hulle nie een van enige historiese waarde oor Jesus se voorgeslagte nie? Die probleme kan vermenigvuldig word: byvoorbeeld, watter evangelie is korrek ten opsigte van die tyd van Jesus se dood (was dit die Vrydag [14 Nissan], die rusdag voor die Paasfees en die dag waarop die paaslammers geslag is voor die fees, soos Johannes berig, of die Vrydag [15 Nissan] die eerste dag van die Paasfees, soos die sinoptici berig)? Afhangend van hierdie dag, kon dit in die jaar 30 of 33 gewees het (toe 14 Nissan op 'n Vrydag geval het) of die jaar 34, toe 15 Nissan op 'n Vrydag geval het (sien Theissen \& Merz 1998:157-160).

Die keuse is nie tussen die aanvaarding van alles in die evangelies, versus diegene wat net sekere dele as outentiek beskou nie (soos die Jesus Seminaar doen nie), maar tussen watter oplossing die beste verkla- ring bied. Dit sal later breedvoerig bespreek word, maar die keuse is tussen diegene wat die narratiewe raamwerk van die sinoptici aanvaar, en al die nie-outentieke dele uitsny (en natuurlik harmonieer tussen die sinoptiese evangelies), en diegene (soos die Jesus Seminaar) wat die probleem oplos deur middel van 'n onafhanklike soeke na die outentieke dele in al die evangelies (en dus nie meer met die nie-outentieke dele hoef te handel nie).

Hierdie probleme kan natuurlik nie op eenvoudige maniere hanteer word nie. Waarom sal mens byvoorbeeld aanvaar dat een (of geeneen) van die geslagsregisters het korrekte historiese gegewens weergegee nie, maar aanvaar dieselfde skrywer(s) het korrekte historiese gegewens wanneer dit by die geboorte- of opstandingsverhale kom?

\subsection{Historiese wanvoorstellings in die evangelies noodsaak sulke navorsing}

Met die eerste oogopslag klink dit verregaande om so 'n uitspraak te maak, maar dit is eenvoudig so dat daar talle voorstellings in die evangelies voorkom wat nie met die historiese werklikheid ooreenstem nie. Dit kan die gevolg wees van die oningeligtheid van die evangelieskrywers, of hulle geografiese en kronologiese afstand vanaf die gebeure en omstandighede self, of selfs die feit dat hulle oor Jesus geskryf het in terme wat ontleen is aan hul eie konteks.

Een voorbeeld van 'n historiese wanvoorstelling het te doen met die verkoop van diere in die tempelvoorhowe. Volgens Johannes 2:14-16 sou Jesus 'n sweep gevleg het en die trop beeste en skape uit die tempel gedryf het. Hoe daar ookal probeer word om hierdie voorstelling waar te maak, blyk dit op die ou einde die beste te wees om toe te gee dat Johannes oningelig was oor die situasie en omstandighede in die tempel (sien Sanders 1992:87-88).

Mens kan ook dink aan die verhale oor Jesus se geboortedatum. Hy kon nie in beide $6 \mathrm{nC}$ (Lukas 2:1 reken dit was in die tyd van Quirinius se sensus) en $4 \mathrm{nC}$ (Matteus stel dit tydens Herodus die Grote, wie in 4 $\mathrm{vC}$ gesterf het, se leeftyd) gebore gewees het nie.

\subsection{Die populêre beeld van Jesus noodsaak die vraag}

Daar bestaan, wat mens sou kon noem, 'n populêre beeld van Jesus wat deur die eeue heen oorgelewer is en veral in die konvensionele uitbeelding van Jesus neerslag gevind het. Hiervolgens glo talle mense (selfs talle mense buite die Christendom deel die oortuiging) dat Jesus 'n soort goddelike of semi-goddelike persoon was (in moderne taal, 'n soort Superman) wat wonders kon doen, aarde toe gekom het met die doel om te sterf vir mense se sondes en so die ewige lewe verseker het (sien Borg 1987:2-4; Sanders 1993:133-135; Funk 1996:48-49 vir meer besonder- 
hede). Die ekstreme eksponent van hierdie beeld vind mens in die spekulasie van diegene wat wonder hoe vinnig Jesus die myl sou kon hardloop, of, indien hy deelgeneem het, hoeveel goue medaljes hy by die pas afgelope Olimpiese Spele sou gewen het. Hierdie beeld van Jesus as goddelike superhero is waarskynlik die mees populêre standpunt onder beide Christene en nie-Christene (sien Borg 1987:7).

Dit is inderdaad so dat die vroeë kerk geglo het dat Jesus transendent is, dat God hom gestuur het, en dat hy spoedig weer sal terugkeer om die wat in hom glo te red (sien Sanders 1985:21). Hierdie oortuigings en hulle ontstaan is deel van die vraag waaroor historiese navorsing rakende Jesus handel, maar dit sal fataal wees om sondermeer te aanvaar dat hierdie oortuigings ook gekorrespondeer het met Jesus as historiese figuur op aarde. Ironies genoeg is hierdie soort perspektief reeds in die vroeë kerk afgewys as die dwaalleer van dosetisme. Dit is die siening dat Jesus eintlik 'n god was en net oënskynlik 'n mens. Jesus as historiese figuur was nie almagtig of alomteenwoordig of enige soort supermens nie. Behalwe dat hierdie beeld van Jesus van Nasaret gewoon histories nie korrek is nie en dikwels op 'n geloofsoortuiging berus, moet in gedagte gehou word dat dit ook op 'n historiese konstruksie berus. Dit sal duidelik word wanneer die verskillende benaderinge in historiese Jesus navorsing bespreek word, dat hierdie historiese konstruksie inderdaad uiters problematies is. Maar dit neem nie weg dat ook hierdie voorstelling van Jesus nie maar net daar is nie - dit is soos al die ander gebou op ' $n$ soort historiese interpretasie. Juis daarom moet dit ook aan die kritiek van historiese navorsing onderwerp word.

Sonder om die belang van enige van hierdie redes te minag, sal later aangetoon word dat vernuwing in historiese Jesus navorsing ook op hierdie punt nodig is. Daar is egter, myns insiens, 'n ander en meer belangrike rede waarom hierdie navorsing noodsaaklik is: Jesus as historiese figuur, die soort verhale oor hom, die ontstaan en oorlewering van die tradisies - in kort, alles rakende hierdie figuur -kom uit 'n kulturele wêreld ver verwyderd van moderne Westerlinge. Hierop sal later terug-
gekeer word

\subsection{Samevatting}

Om saam te vat, die redes vir 'n historiese ondersoek na die persoon, Jesus van Nasaret, is byna oneindig. Dit sluit in die vraag of die voorstellings soos dit in die bronne gevind kan word, net so aanvaar kan word, en indien wel, watter bron s'n aanvaar moet word. Daarby kom nog die probleem wat gedoen moet word met die verhale en uitsprake wat vreemd en anders voorkom, asook die feit dat die populêre voorstelling van Jesus ook op 'n historiese konstruksie berus. Voordat die historiese ondersoek na Jesus van Nasaret afgemaak kan word as oorbodig, moet besef word dat selfs met die konvensionele voorstellings van Jesus, historiese interpretasie ter sprake is. Hierdie voorstelling gaan nie histories waar word net omdat dit aanhoudend herhaal word nie.

Hoewel daar geen eenstemmigheid is presies waarom die figuur van Jesus histories gesproke 'n probleem is nie, kan niemand daarop aanspraak maak dat sy of haar siening van Jesus vry is van die probleme nie. Met ander woorde, die bronne self dwing ons om sekere vrae te vra en sekere keuses te maak ten opsigte van dit wat kon gebeur, kon gesê en kon gewees het in Jesus se lewe.

Om bogenoemde probleme en komponente in die Jesus vraagstuk aan te spreek, is daar 'n groot verskeidenheid benaderinge ontwikkel. Afhangend van op watter area gefokus word, en watter motivering vir navorsing oor die historiese Jesus prioriteit geniet, word verskillende benaderinge gevolg om Jesus as historiese figuur te beskrywe. Begrip vir die redes vir historiese Jesus navorsing, en insig in die verskeidenheid vrae wat ter sprake is, is maar die punt van die ysberg. Elk van die talle komponente wat reeds genoem is, kry 'n ander karakter en belangrikheid, afhangend van watter benadering gevolg word.

Dit is natuurlik, streng gesproke, onbillik om van benaderinge te praat omdat elke navorser eintlik 'n eie stempel afdruk en niemand volledig binne enige benadering tuis hoort nie. Ten spyte van hierdie tekortkominge en voorbehoude is daar tog sekere tendense en patrone wat betekenisvol is. Onder die ban van oorvereenvoudiging van 'n komplekse veld van navorsing, sal drie benaderinge verduidelik word.

\section{DIE BENADERING VAN DIE JESUS SEMINAAR}

\subsection{Wat is die Jesus Seminaar?}

Die Jesus Seminaar bestaan uit ongeveer 200 geleerdes wat reeds die afgelope aantal jare (ongeveer 15) op 'n gereelde grondslag in die VSA ontmoet om aan historiese Jesus navorsing aandag te gee. 'n Verskeidenheid publikasies het reeds as produk van die projek verskyn, terwyl individuele lede van die Jesus Seminaar ook afsonderlik publikasies oor die historiese Jesus laat verskyn het. Met ander woorde, alhoewel die Jesus Seminaar as 'n groep navorsers saamwerk en gesamentlike publikasies die lig laat sien, opereer hulle ook afsonderlik van mekaar. Dit maak dit daarom moeilik, maar nie ontmoontlik nie, om van 'n Jesus Seminaar benadering as sodanig te praat.

Die opspraakwekkendste aspek van hulle navorsing is ongetwyfeld die sogenaamde stemming ("voting") oor die outentieke Jesus se woorde en dade. Met behulp van vier kleure is gestem of spesifieke uitsprake of dade wel aan Jesus toegeskryf kan word (sien Funk \& The Jesus Seminar 1998:8). Vir die woorde van Jesus is die volgende definisies gebruik.

ISSN 1609-9982 = VERBUM ET ECCLESIA Jrg 22 (1) 2001 
Rooi - Jesus het dit gesê

Pienk - Jesus het waarskynlik iets soos dit gesê

Grys - dit is nie Jesus se woorde nie, maar die idee is na genoeg aan syne

Swart - Jesus het dit nie gesê nie, maar die vroeë kerk

Vir die Jesus dade is die volgende definisies gebruik:

Rooi - die rapport is histories betroubaar

Pienk - die rapport is waarskynlik betroubaar

Grys - die rapport is waarskynlik onbetroubaar

Swart - die verslag is onwaarskynlik

Volgens hierdie maatstaf gemeet, het slegs $16 \%$ van die verhale oor Jesus se optrede in die rooi/pink kategorieë van histories betroubaar geval en $84 \%$ in die grys/swart kategorieë terwyl net $18 \%$ van die woorde in die evangelies aan Jesus self toegeskryf word (sien Funk \& The Jesus Seminar 1998:1)

Alhoewel die Jesus Seminaar soos dit hier bespreek word geen homogene groep geleerdes is nie (en nie eens almal noodwendig met die publikasies onder die naam van die Jesus Seminaar saamstem nie), is daar tog sekere patrone en tendense wat te voorskyn tree. Sonder om te beweer dat elke lid van die Jesus Seminaar sal saamstem met elk van die punte wat bespreek sal word, sal daar telkens aangedui word wie aan die woord is.

\subsection{Die benadering van die Jesus Seminaar}

Dit is veral lede van die Jesus Seminaar wat deesdae die standpunt huldig dat 'n duidelike onderskeid tussen die "historiese Jesus" en die "verkondigde Christus" gemaak moet word (of, tussen die "evangelie van Jesus" en die "Jesus van die evangelies"; ook beskryf as die "godsdiens van Jesus" teenoor die "godsdiens oor Jesus"). Die wyse waarop die probleme van die verskille tussen die bronne en binne-in die bronne hanteer word, is om te anvaar dat die eerste taak daarin bestaan om te onderskei tussen dit wat teruggaan op Jesus self en dit wat deur sy volgelinge en die vroeë kerk bygevoeg is (sien Borg 1999a:11; Funk 1996:64; Crossan 1998:140).

Om by die historiese persoon uit te kom, moet die outentieke Jesus materiaal eers vasgestel word, en dan van die latere toevoegings onderskei word. Outentieke materiaal word op verskillende maniere vasgestel. Eerstens word met behulp van die vasstelling van die oudste bronne wat meer as een keer oorgelewer is, die outentieke basis in Jesus se onderrrig bepaal. Dit word dan gebruik om te besluit oor ander aspekte wat outentiek mag wees. Die besluit oor outentisiteit in die vertellingsmateriaal loop effens anders. Hier is die sentrale kriterium of iets histories is, met ander woorde, of dit histories moontlik is en/of ooreenstem met ander historiese feite. Elkeen van die aspekte sal kortliks verduidelik word.

\subsubsection{Die onderskeid tussen die historiese Jesus en die verkondigde Christus}

Die kenmerk van egte wetenskaplike Jesus navorsers, volgens die Jesus Seminaar, is dat 'n onderskeid getref word tussen die historiese Jesus en die verkondigde Christus en dat die onderskeid daadwerklik aangespreek word. Dit word gedoen deur die outentieke (Jesus) van die nie-outentieke (Christus) materiaal te skei. Die eerste taak in die proses is om die uitsprake, gelykenisse en dade van Jesus self in twee groepe te verdeel: dit wat aan Jesus van Nasaret toegeskryf kan word en dit wat die produk van die vroeë volgelinge van Jesus of van die vroeë kerk af kom. Anders gestel, vir lede van die Jesus Seminaar was die historiese Jesus anders as die Jesus wat ons in die evangelies vind en die Jesus van die belydenisse wat daarop voortgebou het (sien Funk 1996:64-65, Van Aarde 2000:550551).

Gebaseer op die feit dat elke evangelie 'n eie weergawe van Jesus gee, word beklemtoon dat die historiese persoon verskil het van die profiel wat elke evangelis van hom teken (sien Funk 1996:59). Dus, die verskille tussen die evangelies bevestig dat Jesus se eerste volgelinge sy lewe en optrede beskryf het vanuit hulle eie perspektiewe - gewoonlik gekleur met 'n eie na-pase teologiese perspektief. Hierdie perspektief was dié van hulle ervaring van Jesus as geestelike, goddelike wese en opgestane Heer, wat dan deur die evangeliste op die lewe van Jesus terug geprojekteer word. Die opstandingservaring sou die perspektief van Jesus se volgelinge sodanig gekleur het dat alles in die evangelies aan die Christus van die geloof toegeskryf word.

Dit is belangrik om te besef dat volgens hierdie benadering die onderskeid reeds in die Nuwe-Testamentiese dokumente self begin en deur die vroeë kerkvaders verder gevoer word. Met ander woorde, sommige volgelinge van Jesus was self aandadig om die historiese persoon te transformeer in 'n soort mitiese gode-figuur. Daar is ook reeds daarop gewys dat die populêre beeld van Jesus verskil van die historiese persoon wat in Galilea geleef het. Die Jesus Seminaar skryf daardie verskil toe aan hierdie onderskeid tussen die historiese Jesus en die verkondigde Christus wat reeds in die vroegste Christelike dokumente sigbaar is. Daarom moet die evangelies gesuiwer word van die mitologiese elemente om by die historiese persoon uit te kom (sien Funk 1996:59).

ISSN 1609-9982 = VERBUM ET ECCLESIA Jrg 22 (1) 2001 
Rooi - Jesus het dit gesê

Pienk - Jesus het waarskynlik iets soos dit gesê

Grys - dit is nie Jesus se woorde nie, maar die idee is na genoeg aan syne

Swart - Jesus het dit nie gesê nie, maar die vroeë kerk

Vir die Jesus dade is die volgende definisies gebruik:

Rooi - die rapport is histories betroubaar

Pienk - die rapport is waarskynlik betroubaar

Grys - die rapport is waarskynlik onbetroubaar

Swart - die verslag is onwaarskynlik

Volgens hierdie maatstaf gemeet, het slegs $16 \%$ van die verhale oor Jesus se optrede in die rooi/pink kategorieë van histories betroubaar geval en $84 \%$ in die grys/swart kategorieë terwyl net $18 \%$ van die woorde in die evangelies aan Jesus self toegeskryf word (sien Funk \& The Jesus Seminar 1998:1)

Alhoewel die Jesus Seminaar soos dit hier bespreek word geen homogene groep geleerdes is nie (en nie eens almal noodwendig met die publikasies onder die naam van die Jesus Seminaar saamstem nie), is daar tog sekere patrone en tendense wat te voorskyn tree. Sonder om te beweer dat elke lid van die Jesus Seminaar sal saamstem met elk van die punte wat bespreek sal word, sal daar telkens aangedui word wie aan die woord is.

\subsection{Die benadering van die Jesus Seminaar}

Dit is veral lede van die Jesus Seminaar wat deesdae die standpunt huldig dat 'n duidelike onderskeid tussen die "historiese Jesus" en die "verkondigde Christus" gemaak moet word (of, tussen die "evangelie van Jesus" en die "Jesus van die evangelies"; ook beskryf as die "godsdiens van Jesus" teenoor die "godsdiens oor Jesus"). Die wyse waarop die probleme van die verskille tussen die bronne en binne-in die bronne hanteer word, is om te aanvaar dat die eerste taak daarin bestaan om te onderskei tussen dit wat teruggaan op Jesus self en dit wat deur sy volgelinge en die vroeë kerk bygevoeg is (sien Borg 1999a:11; Funk 1996:64; Crossan 1998:140).

Om by die historiese persoon uit te kom, moet die outentieke Jesus materiaal eers vasgestel word, en dan van die latere toevoegings onderskei word. Outentieke materiaal word op verskillende maniere vasgestel Eerstens word met behulp van die vasstelling van die oudste bronne wat meer as een keer oorgelewer is, die outentieke basis in Jesus se onderrrig bepaal. Dit word dan gebruik om te besluit oor ander aspekte wat outentiek mag wees. Die besluit oor outentisiteit in die vertellingsmateriaal loop effens anders. Hier is die sentrale kriterium of iets histories is, met ander woorde, of dit histories moontlik is en/of ooreenstem met ander historiese feite. Elkeen van die aspekte sal kortliks verduidelik word.

\subsubsection{Die onderskeid tussen die historiese Jesus en die verkondigde Christus}

Die kenmerk van egte wetenskaplike Jesus navorsers, volgens die Jesus Seminaar, is dat 'n onderskeid getref word tussen die historiese Jesus en die verkondigde Christus en dat die onderskeid daadwerklik aangespreek word. Dit word gedoen deur die outentieke (Jesus) van die nie-outentieke (Christus) materiaal te skei. Die eerste taak in die proses is om die uitsprake, gelykenisse en dade van Jesus self in twee groepe te verdeel: dit wat aan Jesus van Nasaret toegeskryf kan word en dit wat die produk van die vroeë volgelinge van Jesus of van die vroeë kerk af kom. Anders gestel, vir lede van die Jesus Seminaar was die historiese Jesus anders as die Jesus wat ons in die evangelies vind en die Jesus van die belydenisse wat daarop voortgebou het (sien Funk 1996:64-65, Van Aarde 2000:550 551).

Gebaseer op die feit dat elke evangelie 'n eie weergawe van Jesus gee, word beklemtoon dat die historiese persoon verskil het van die profiel wat elke evangelis van hom teken (sien Funk 1996:59). Dus, die verskille tussen die evangelies bevestig dat Jesus se eerste volgelinge sy lewe en optrede beskryf het vanuit hulle eie perspektiewe - gewoonlik gekleur met 'n eie na-pase teologiese perspektief. Hierdie perspektief was dié van hulle ervaring van Jesus as geestelike, goddelike wese en opgestane Heer, wat dan deur die evangeliste op die lewe van Jesus terug geprojekteer word. Die opstandingservaring sou die perspektief van Jesus se volgelinge sodanig gekleur het dat alles in die evangelies aan die Christus van die geloof toegeskryf word.

Dit is belangrik om te besef dat volgens hierdie benadering die onderskeid reeds in die Nuwe-Testamentiese dokumente self begin en deur die vroeë kerkvaders verder gevoer word. Met ander woorde, sommige volgelinge van Jesus was self aandadig om die historiese persoon te transformeer in 'n soort mitiese gode-figuur. Daar is ook reeds daarop gewys dat die populêre beeld van Jesus verskil van die historiese persoon wat in Galilea geleef het. Die Jesus Seminaar skryf daardie verskil toe aan hierdie onderskeid tussen die historiese Jesus en die verkondigde Christus wat reeds in die vroegste Christelike dokumente sigbaar is. Daarom moet die evangelies gesuiwer word van die mitologiese elemente om by die historiese persoon uit te kom (sien Funk 1996:59).

ISSN 1609-9982 = VERBUM ET ECCLESIA Jrg 22 (1) 2001 
In die navorsingsgeskiedenis is hierdie onderskeid reeds deur Martin Kähler getref en veral in die Bultmann-skool benut. Ironies genoeg, die aanvanklike oorsprong daarvan was juis daarop gemik om die tradisionele sieninge oor Jesus te beskerm teen historiese kritiek (sien Meier 1990:4-14). Vandag word dit veral gebruik om die historiese persoon los te maak van die mitologiese.

Dit is egter belangrik om daarop te wys dat dit nóg essensieel nóg algemeen tot historiese Jesus navorsing is om hierdie onderskeid op die manier van die Jesus Seminaar te handhaaf. Ironies genoeg is dit juis lede van die Jesus Seminaar (wat baie skepties staan teenoor die meeste mitologiese elemente in die evangelies), wat aan die opstanding (of ten minste dan aan die opstandingsgeloof) 'n baie prominente historiese posisie toeken. Hulle meen dat die opstanding 'n fenomenale gebeure moes gewees het, wat die totale perspektief van Jesus se volgelinge so verander het dat hulle hom in 'n mitologiese figuur getransformeer het.

\subsubsection{Outentieke Jesus materiaal}

As die eerste pilaar van die Jesus Seminaar is om Jesus van die Christus figuur te onderskei, is die tweede om die outentieke materiaal wat van Jesus self af kom, te identifiseer. Volgens hierdie navorsers is die populêre beeld van Jesus reeds deur die evangeliste op die lewe van die historiese persoon geprojekteer. Dus, om by die historiese figuur uit te kom, moet die latere toegevoegde elemente afgestroop word. Om te kan weet wat Jesus self sou gesê en gedoen het, moet 'n inventaris van outentieke Jesus materiaal vasgestel word waarop 'n beeld van hom as historiese persoon gebou kan word. As daar enige twyfel bestaan of Jesus iets sou gesê of gedoen het, word daardie perikoop eerder uitgeskakel as ingesluit (sien Crossan 1991a:xxx-xxxiii; Funk 1996:139; Borg 1999a:11-13).

Outentieke materiaal word op verskillende maniere vasgestel. Eerstens word met behulp van die datering van die oudste bronne wat meer as een keer oorgelewer is, die outentieke basis in Jesus se onderrig bepaal ('n inventaris van alle outentieke materiaal). Op die basis van hierdie beginsel (wat natuurlik 'n vroeë datering van die Evangelie van Tomas insluit) is gevind dat dit kenmerkend van Jesus was dat hy in gelykenisse en kort spreuke (aforismes) gepraat het. Die $18 \%$ outentieke materiaal (woorde of uitsprake) wat na Jesus self teruggevoer word, bestaan dus uit gelykenisse en aforismes. Soos Funk (sien 1998:9) sê, dit vorm die fondament van die tradisie en verteenwoordig die gesigspunt van Jesus self. Dit word dan gebruik om te besluit oor ander aspekte wat outentiek mag wees.

Die besluit oor outentisiteit in die vertellingsmateriaal loop effens anders. Hier is die sentrale kriterium of iets histories is, met ander woor- de, of dit histories moontlik is en/of ooreenstem met ander historiese feite. Laasgenoemde beteken veral of vertellinge in lyn is met dit wat histories oor Jesus vasgestel kan word deur na die outentieke uitsprake te kyk. Verteenwoordig die verhale oor Jesus dieselfde soort persoon as wat in die verhale na vore tree (sien Funk \& The Jesus Seminaar 1998:32-35). Die verdere toets vir outentisiteit is of die voorstellings in 'n verhaal histories moontlik is (sien Funk \& The Jesus Seminaar 1998:24; Lüdemann 1998:10-24). Met ander woorde, waar byvoorbeeld natuurwette verbreek word, of legendariese elemente te bespeur is, het ons met nie-outentieke verhale te make (soos Jesus se doop, die verheerliking op die berg en die loop op die see).

\subsubsection{Positiwistiese geskiedbeskrywing: historisiteit van gebeure en} die vertroue op realia

Die derde (meestal onsigbare) pilaar van hierdie benadering is 'n naturalistiese (of positiwistiese) filosofie. Dit kom na vore in drie fasette wat reeds genoem is.

Eerstens, die aandrang dat net dit wat werklik kon gebeur het (beoordeel vanuit 'n positiwistiese wêreldbeeld), histories kan wees. Byvoorbeeld, die verhaal van Jesus wat op die see geloop het (Mk 6:4752 ), is nie histories betroubaar nie ( $\mathrm{m} \mathrm{a} \mathrm{w}$, dit was geen historiese gebeure nie, want Jesus het nie werklik op die water geloop nie - sien Funk \& The Jesus Seminaar 1998:93). Die aanname van die benadering is dat die verhaal handel oor ' $n$ persoon wat op water kan loop, en dit is in beginsel nie moontlik nie. Die punt is nie om te beweer dat Jesus wel op water geloop het nie (dit is om dieselfde kriterium te gebruik), maar om te beklemtoon dat die maatstaf van die positiwistiese wetenskap gebruik word om te beoordeel waaroor die storie eintlik handel.

Tweedens kom die filosofie na vore in die epistemologiese uitgangspunt dat net materiaal wat direk van Jesus afkomstig is, toegang tot hom as historiese persoon gee. Met ander woorde, slegs as vasgestel kan word wat hy self gesê en werklik gedoen het, kan iets oor hom as historiese persoon geweet word.

Derdens berus die onderskeid tussen die historiese persoon en die mitologiese Christus op die aanname dat alles wat nie in 'n positiwistiese wêreldbeeld inpas nie, mitologies of onhistories is. Hierdie onderskeid is slegs moontlik, soos Smith (sien 1978:4) uitgewys het, indien aanvaar word dat Jesus as historiese persoon 'n nie-mitologiese figuur was (bloot 'n soort leraar van nuwe waarhede).

Sonder om elk van die aspekte breedvoerig te probeer bespreek, is dit voldoende om die belangrike punt te bevestig dat die Jesus Seminaar se wêreldbeeld en geskiedbeskrywing deur en deur positiwisties is (iets 
wat hulle eintlik geredelik toegee, sien Funk, Hoover and The Jesus Seminar 1993:1-5).

Ernstige vrae word egter gevra oor talle aannames in hierdie benadering. Daar is twyfel of die bronne hoegenaamd met behulp van die argeologiese lae-model bestudeer kan word (sien Kelber 1994:140-151; Freyne 1997:64) en of dit hoegenaamd moontlik is om sogenaamde outentieke materiaal te skei van die tradisie; soos Allison (sien 1998:33) opmerk, is dit moontlik om chemiese elemente met ' $n$ mes te skei? Dan is die vraag nog nie eens gevra of dit hoegenaamd wenslik is om vanuit enkele outentieke woorde of dade te probeer aflei wie en wat ' $n$ persoon is of was nie. Dit vat nie veel om aan te toon dat nie net dit wat gebeur het of gesê is, deel van iemand se biografie is nie (vra maar vir Bill Clinton en Monica Lewinsky). In beginsel is dit natuurlik belangrik dat historiese uitsprake moet berus op 'n vaste basis van geldige historiese bronne. Maar dit beteken nie noodwendig dat slegs dit wat iemand self gesê het, die enigste bron van historiese kennis oor daardie persoon is nie.

\subsection{Opsommend}

Dit is duidelik dat die Jesus Seminaar op 'n spesifieke manier omgaan met die verskillende vrae wat in Jesus navorsing gevra word. Die beginpunt is wat Jesus self gesê het en dit wat hy gedoen het. Aspekte van Jesus se biografie word beoordeel aan die hand van hierdie vertrekpunt, naamlik, outentieke en historiese materiaal. Daaruit word dan gekonkludeer watter soort persoon hy as historiese figuur was. Aangesien Jesus se onderrig of lering sentraal staan in hierdie soort analise (met ander woorde, dit wat hy gesê het), word gekonkludeer dat die historiese Jesus ' $n$ wysheidsleraar van een of ander aard was.

Dit is ook belangrik om op te merk dat lede van die Jesus Seminaar redelik konsekwent begin met die vraag wat Jesus sou gesê het. Dan word gevra na wat hy sou gedoen het, en dan word gekonkludeer watse soort figuur hy was. Een van die onderliggende aannames tot die histories kritiese onderskeid tussen dit wat van Jesus af kom en dit wat die produk van die vroeë kerk is, is dat indien dit van Jesus af kom, dit ook histories korrek is.

Hierdie benadering kan in een kort beskrywing saamgevat word:

Jesus het dit nie gesê nie (dit kom van die vroeë kerk af), of iets het nie gebeur nie (want sulke dinge kan nie gebeur nie), en daarom kom sekere woorde nie van Jesus af nie, of het sekere dinge nie gebeur nie. Die maagdelike geboorte is 'n voorbeeld waar beide 'n rol speel: dit is 'n skepping van die vroeë kerk, en maagde kan in elk geval nie swanger word nie, daarom het Jesus nie 'n maagdelike geboorte gehad nie.

\section{DIE "THIRD QUESTERS" OF TRADISIONELE (TEOLO- GIESE) BENADERINGE}

Net so min as wat daar 'n algehele konsensus onder lede van die Jesus Seminaar bestaan, is daar enige soort konsensus onder diegene wat hier saam gegroepeer word onder die opskrif tradisionele benaderinge. In die navorsingsgeskiedenis is dit die navorsers wat onder die vaandel van die "third quest" opereer. Hulle verteenwoordig die meerderheid navorsers wat op die onderwerp werk (sien byvoorbeeld Wright 1992:800-801 en Blomberg 1995:25-28). Daar is duidelik sekere patrone sigbaar in die wyse waarop hulle met Jesus as historiese figuur omgaan - sonder om te beweer dat alle aspekte gedeel word.

Ten spyte van talle besware uit hierdie oorde, is hierdie benaderinge almal in ' $n$ mindere of meerdere mate slegs pogings om teologiese geskiedenis te skryf; met ander woorde, pogings om bestaande teologiese standpunte 'n historiese basis te gee (sien byvoorbeeld die volgende evaluerings - Marsh 1998; Moxnes 1998:142-143). Myns insiens is Funk (sien 1996:65) heeltemal in die kol wanneer hy sê dat die "third questers" kritiese navorsing bloot tot op die punt neem waar dit nie die belydenisse van die kerk aantas nie. Dit is niks meer as 'n historiese bevestiging van oorgelewerde belydenisse nie. Hierdie is egter nie die fokuspunt van die huidige studie nie. My vraag is watter patrone en tendense is sigbaar in die wyse waarop historiese Jesus navorsing hier bedryf word.

Dit sal aangetoon word dat ten opsigte van sekere fundamentele aspekte die "New Quest" aannames met die Jesus Seminaar deel, maar dit anders inklee. Soos by die Jesus Seminaar, berus hierdie benaderinge eerstens ook op die aanname dat outentieke materiaal die vertrekpunt vorm van historiese Jesus navorsing, en tweedens aanvaar dit ook die naturalistiese wêreldbeeld en filosofie. Ten opsigte van beide is daar egter belangrike verskille aan te dui. Elk van die aspekte sal kortliks verduidelik word.

\subsection{Outentisiteit van die sinoptiese evangelies}

Selfs die mees konserwatiewe eksegete wat die tradisionele benaderinge volg, aanvaar dat die basis van 'n historiese Jesus beeld op outentieke materiaal gebou moet word. Anders as die Jesus Seminaar, is daar twee aspekte wat hier domineer.

Die eerste is dat die vertelraamwerk van die sinoptiese evangelies as basis gebruik word (sien bv Sanders 1993:73; Theissen \& Merz 1998:61). As gevolg van die oormaat van gegewens word aanvaar dat die

ISSN 1609-9982 = VERBUM ET ECCLESIA Jrg 22 (1) 2001 
sinoptici grootliks outentieke materiaal bevat. Hier word met ander woorde 'n groot kern van materiaal as outentiek beskou, teenoor die klein kern outentieke deeltjies deur die Jesus Seminaar. Nie net funksioneer die kriteria van outentisiteit anders nie, dit is ook ander kriteria wat prioriteit geniet in die uitsny van "nie-outentieke" dele. Terwyl die sinoptiese raamwerk as vertrekpunt geneem word, moet bloot die dele wat die vroeë kerk se skeppinge is, uitgehaal word.

Die tweede aspek is dat hierdie navorsers meestal onwillig is om die skerp onderskeid tussen die historiese Jesus en die verkondigde Christus te trek. Hier is die onderskeid eerder tussen die historiese Jesus en die na-pase geloof van sy volgelinge: hulle het sekere van hulle na-pase oortuigings en sieninge op die Jesus van voor pase geprojekteer. Daar word dus erken dat die evangelietradisies gekleur is deur die na-opstandingsgeloof, dat daar talle verskille tussen die evangelies is, en dat daar talle historiese en geografiese wanvoorstellings in die bronne bestaan. Op talle punte word geargumenteer dat 'n sekere logion of vertelling nie op Jesus teruggaan nie, en dus die skepping van die vroeë kerk is (sien bv Theissen \& Merz 1998:254). Met ander woorde, sommige elemente in die evangelies word gesien as die skepping of formulering van mense wat vanuit 'n na-pase perspektief skryf oor Jesus as historiese persoon of ver verwyderd was van die konteks waaroor hulle skryf.

Dit behoort duidelik te wees dat alle navorsers wat daarna streef om outentieke materiaal onder die lae nie-outentieke materiaal te identifiseer, die gevaar loop om data as getuienis te gebruik wat eintlik nie by die saak hoort nie (almal wat aanvaar die na-pase of vroeë kerk materiaal moet eers uitgeskakel word). Dit is natuurlik ' $n$ veel groter probleem vir diegene wat bloot die sinoptiese raamwerk as outentiek aanvaar sonder enige metodologiese stappe om te verseker dat later materiaal nie onregmatig aan Jesus self toegeskryf word nie (sien Borg 1999b:236-237). Dit is daarom " $n$ algemene beskuldiging teen die "New Questers" dat dit veel meer aan Jesus toeskryf as wat geregverdig kan word.

\subsection{Positiwistiese geskiedskrywing (plus die bonatuurlike kategorie)}

Daar is ' $n$ verstommende ironie in die beskuldiging wat dikwels uit tradisionele oorde teen byvoorbeeld lede van die Jesus Seminaar gerig word, naamlik dat hulle positiwistiese oortuigings op 'n geslote wêreldbeeld uitloop, en daarom laat hulle geen ruimte vir sekere verhale, soos oor Jesus se maagdelike geboorte (eerder Jesus se maagdelike konsepsie) of die opstanding nie (sien Du Toit 1997:xii-xiii; Wright 1999c:124). Die volgende is ' $n$ tipiese beskuldiging:
The members of the Jesus Seminar are committed to a strict philosophical naturalism. Modern science and experience demonstrate that supernatural phenomena do not exist. Therefore, any record of supernatural events in the Gospels must be rejected as inauthentic. Recorded supernatural events are either mythic fictions created by the early church, or else they can now be accounted for by naturalistic explanations (Wilkins and Moreland 1995:4).

Dit is ironies dat navorsers wat hierdie standpunt huldig in talle opsigte net so modernisties is as diegene wie hulle daarvan beskuldig. Enkele voorbeelde sal voldoende wees om aan te toon dat navorsers oor ' $n$ breë spektrum (veral die wat nie tuis is in die Jesus Seminaar nie) ook die Jesus tradisies met dieselfde modernistiese wêreldbeeld en positiwistiese geskiedenisfilosofie benader. Veral twee tegnieke word gebruik om 'n groot deel van die tradisie te hanteer (veral die wonderverhale en aspekte oor Jesus se geboorte, doop, verheerliking op die berg, die stryd in Getsemane en die opstandingstradisies).

Die eerste tegniek is om die verhale as na-pase beskrywings te beskou. Anders gestel, dit is verhale wat vanuit 'n na-pase perspektief geskryf is en eintlik 'n terugprojeksie van daardie gesigspunt na die aardse lewe van Jesus verteenwoordig. Dit is byvoorbeeld die geval met die natuurwonders, die verheerliking op die berg, en Jesus se doopverhaal (sien bv Theissen \& Merz 1998:302-304). Diegene wat hierdie tegniek inspan, deel natuurlik die uitgangspunt van die kloof tussen die historiese Jesus en die verkondigde Christus.

Die tweede en meer algemene tegniek, is om die bonatuurlike kategorie in te span om enige buitengewone elemente in die evangelies te hanteer. Dit kom in 'n verskeidenheid van verpakkings wat wissel vanaf die bonatuurlike en die misterieuse tot wonderwerke en God-kan-allesdoen uitsprake. Onderliggend aan elkeen van hierdie pogings is niks anders as 'n moderne, geslote wêreldbeeld nie.

Die patroon is oral dieselfde: dit wat vertel word, kon nie gebeur het soos dit vertel word nie (die logies-positiwistiese filosofie dat dit wat nie empiries aangetoon kan word nie, het nie gebeur nie) en daarom word ' $\mathrm{n}$ addisionele kategorie ingevoer om dit te hanteer. Sanders (sien 1993:280), wat sekerlik beskou kan word as een van die rigtinggewende stemme buite die kring van die Jesus Seminaar, reken dat talle aspekte in die Jesus tradisies 'n misterie bly, en niks is meer misterieus as die opstanding nie. Die sleutelterm in hierdie soort argumente is die bonatuurlike (the supernatural'; sien byvoorbeeld Craig 1995:146; Habermas 1995:127) of die misterieuse.

So reken Wright (sien 1999a:124, 176) ook dat die geboorteverhale hierdie misterieuse teenwoordigheid van God bevat, terwyl iets merk-

ISSN 1609-9982 = VERBUM ET ECCLESIA Jrg 22 (1) 2001 
waardig met Jesus se liggaam gebeur het die Sondagoggend na die kruisiging (sien ook Brown 1973:70-72; O'Collins 1997:12-13). Sommiges gaan so ver as om te beweer dat geeneen van hierdie verhale daarom met behulp van historiese metodes ondersoek kan word nie (sien Johnson 1996:136)

Dit is belangrik om raak te sien dat, soos die lede van die Jesus Seminaar, hierdie navorsers eweveel kinders van hulle tyd is. Hulle glo net so min dat 'n maagdelike geboorte of ' $n$ opstanding uit die dood tot die normale werklikheid behoort. Dit kan slegs geakkommodeer word omdat die addisionele kategorie, bonatuurlike bygevoeg word.

Die ironie waarna hierbo verwys is, kom die helderste na vore in beskuldigings dat diegene wat nie die buitengewone elemente in die evangelies wil aanvaar nie, met 'n geslote, modernistiese wêreld- en geskiedenisbeeld van oorsaak en gevolg werk (sien byvoorbeeld Du Toit 1980:277; Wright 1999a:173,177; Wilkins \& Moreland 1995:8). Dit is natuurlik geen "oop" wêreldbeeld om die modernistiese een te aanvaar en dan, net wanneer nodig bloot aan te vul met iets soos "God kan wonders doen" of "iets misterieus het gebeur" nie. Dit is juis " $n$ geslote wêreldbeeld wanneer alles wat gebeur in die stelsel ingesluit kan word (niks kan gebeur waarvoor daar nie 'n verklaring in terme van die stelsel is nie). Die enigste voorwaarde is natuurlik dat in hierdie geval niemand anders (historiese navorsing) toegang tot die gebeure wat misterieus verklaar is, het nie.

Sonder om dit hier volledig te doen, kan hierdie beskrywing van die modernistiese wêreldbeeld nog van 'n ander hoek af bekyk word. Geen eerste-eeuse persoon het die onderskeid van natuurlik versus bonatuurlik aangelê soos dit hier gedoen word nie. Die kategorie "bonatuurlik", soos dit in al sy variasies hier gebruik word, is 'n moderne Westerse kategorie wat die "natuurlike orde" veronderstel (sien byvoorbeeld Saler 1977). Die meeste elemente wat in hierdie argumente as bonatuurlik of misterieus aangedui word, was integraal deel van die "natuurlike orde" in daardie wêreld. Dit moet hier duidelik gestel word: die eerste-eeuse wêreldbeeld was nie identies aan hierdie moderne wêreldbeeld plus die sogenaamde bonatuurlike of misterieuse elemente nie. Hierdie is nie net ' $n$ vervalsing van hulle wêreldbeeld nie, maar ook ' $n$ wanvoorstelling asof diegene wat ruimte laat vir die bonatuurlike of misterieuse, ook getrou is aan die bybelse wêreldbeeld.

Hoe word bewys dat sulke bonatuurlike gebeure buite die bereik van historiese navorsing is (as dit vir die historikus verbode terrein is, wonder mens hoe kry hierdie navorsers dit reg om so ' $n$ sterk historiese uitspraak te maak dat daar gebeure is wat plaasgevind het wat wonders is)? Die antwoord is eenvoudig deur bloot die gevolgtrekking in die premisse in te sluit (sien Miller 1998:33. vir 'n soortgelyke analise).
Die modernisme (positiwisme) van hierdie benadering kan ook in een kort beskrywing saamgevat word.

Sekere dinge gebeur normaalweg nie, maar God kan wonders doen, en daarom kon Jesus sekere dinge gesê en veral gedoen het. Byvoorbeeld, maagde word normaalweg nie swanger nie, maar in die geval Maria van Nasaret, het God op een of ander manier ingegryp en 'n wonder het gebeur. Daarom word die meeste van die sinoptiese tradisies aanvaar, want by God is omtrent alles moontlik.

\subsection{Opsommend}

Opsommenderwys kan gesê word dat die tendens in hierdie benadering is om te begin met die aanname dat die sinoptiese evangelies betroubare en outentieke materiaal bevat en as basis gebruik moet word vir ' $n$ hipotese oor watse soort figuur Jesus was. Hierdie hipotese funksioneer dan deurgaans om alles wat Jesus gesê en gedoen het, te beskryf. Die filoso-

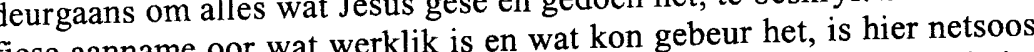
in die benadering van die Jesus Seminaar, suiwer naturalisme (positiwisin die ben groot verskil, naamlik, dat in hierdie me). Soos aangedui, is daar die een groot verskil, naamlik, dat in hierdik gebenadering daar voortdure oor Jesus te verstaan: die bonatuurlike, of

maak word om die verhale oor Jesus te verstat
wonders of die God-kan-alles-doen kategorie.

\section{VERNUWING IN HISTORIESE JESUS NAVORSING: 'N} APOLOGIE VIR 'N KULTUUR SENSITIEWE BENADERING

Daar is vandag talle studies wat daarop aanspraak maak om 'n derde alternatief naas bogenoemde benaderinge te wees (sien, byvoorbeeld an Aarde 2000:553), of om die eerste-eeuse Mediterreense kulturele sisteem ernstig op te neem (sien as voorbeeld Crossan 1991a). Beide hierdie studies maak inderdaad plek-plek gebruik van insigte uit die sosiale wetenskappe of neem aspekte van die kulturele sisteem ernstig op. Soos reeds gesê, word onder vernuwing in hierdie studie egter iets . Vernuwing beteken nie om nuwe antwoorde op ou vrae te gee nie, maar om nuwe vrae te vra en nuwe rigtings in te 列 insigte, of die gebruik van sosiaal-wetenskaplike modelle (veral uit Antropologie) binne die bestaande raamwerk nie, maar op ' $n$ fundamen( navorsing. Dit gebruik insigte uit veral die sosiale wetenskappe om die kulturele sisteem te konstrueer en elke aspek ten opsigte van Jesus as historiese figuur te verstaan. Dit sluit in die soort figuur wat hy was, die ontstaan en oorlewering van die verhale oor hom, die soort kontekste waarin hy opgetree het, en die volgelinge wat hy gehad het.

ISSN 1609-9982 = VERBUM ET ECCLESIA Jrg 22 (1) 2001 
Die dominante kenmerke van die eerste twee benaderinge, is gesê, is dat dit gebou is op die soeke na outentieke materiaal (min in die geval van die Jesus Seminaar, en baie in die geval van die New Quest) en op 'n positiwistiese wêreld- en geskiedbeskouing. Hierteenoor vertrek die kultuur-sensitiewe benadering van 'n geheel ander stel uitgangspunte en totaal ander veronderstellinge. 'n Historiese figuur word nie gekonstrueer aan die hand van outentieke materiaal nie, maar met behulp van 'n sosiale analise. Die geskiedenis filosofie is nie positiwisties nie, maar interpretatief. Die fokus is nie op wat Jesus sou gesê of gedoen het nie, maar op watse soort persoon hy was (later meer hieroor, maar hiermee kan die "waaroor-vraag" getransformeer word). Historiese Jesus navorsing word nie in die eerste plek gedoen omdat die bronne van mekaar verskil, en dit onduidelik is wat Jesus sou gesê en gedoen het nie, maar omdat sy lewe en optrede, asook die bronne oor hom, uit ' $n$ ander kulturele sisteem stam (hiermee kan die "waarom-vraag" getransformeer word) .

Die dominante kenmerk van hierdie benadering is dus dat hierdie insigte nie net bygetrek word om byvoorbeeld Jesus se geboorteverhale of genesingsverhale te verstaan nie, maar om die totale figuur asook die bronne en historiese Jesus navorsing as sodanig in 'n ander kulturele raamwerk te beoordeel. Dit is uiteraard onmoontlik om hier enigsins volledig te probeer wees. Daarom sal, veral in kontras met die voorafgaande benaderinge, slegs enkele lyne getrek word. Aangesien dit onmoontlik is om elk van die aspekte hier breedvoerig te bespreek, sal slegs enkele van die aannames en implikasies van die benadering bespreek word. Dit sal voldoende wees om die raamwerk te verskaf waarbinne van vernuwing in historiese Jesus navorsing gepraat kan word.

\subsection{Die kulturele gaping met die wêreld van Jesus noodsaak \\ historiese navorsing}

Vernuwing begin reeds by die formulering van die redes waarom historiese Jesus navorsing noodsaaklik is. Dit gaan nie in die eerste plek oor die verskille tussen die bronne of hul historiese probleme nie, maar oor die kulturele gaping tussen die wêreld van Jesus en die moderne navorser. Selfs al was die bronne eenstemmig (en selfs daar waar hulle eenstemmig is oor byvoorbeeld genesings of eksorsismes), is die eerste en belangrikste probleem dat Jesus opgetree het, die verhale ontstaan het en oorgelewer is en sin gemaak het in 'n wêreldbeeld en kulturele sisteem ver verwyderd van dié van moderne navorsers. Dit is fundamenteel aan hierdie benadering dat in gedagte gehou word dat nie net individuele elemente in die evangelies nie, maar Jesus as historiese figuur, die verhale oor hom, die ontstaan en oorlewering van die tradisies - alles rakende hierdie figuur - in 'n pre-industriële, voor-drukkuns, agrariese wêreld en wêreldbeeld van die eerste-eeuse Mediterreense omgewing ontstaan en plaasgevind het.

Dit is algemene kennis dat die Jesus tradisies baie elemente bevat wat mense vandag nie as "normale" alledaagse verhale beskou of kan beskou nie. Byvoorbeeld: dat Jesus as Seun van God beskou word, aansprake dat sy geboorte nie deur gewone menslike seksuele omgang voorafgegaan is nie, en talle wonderbaarlike gebeure wat aan sy toedoen toegeskryf word. So ook bevat die uitspake wat aan Jesus toegedig word baie onduidelikhede: byvoorbeeld, uitsprake oor 'n Koninkryk of heerskappy van God wat op hande is en verwysings na 'n wederkoms van 'n gestorwe en opgestane persoon. Niemand kan ontken dat hierdie verhale vir baie mense buitengewoon oorkom nie. Alle navorsers stem saam dat die evangeliemateriaal 'n spesiale uitdaging stel aan interpreteerders. Sommiges verwerp dit as mites en ander hanteer dit as misterieuse verhale met bonatuurlike elemente. In hierdie benadering word dit as egte kulturele uitdrukkings uit ' $\mathrm{n}$ ander tyd en raamwerk hanteer. Die aard en eie kulturele sisteem van die verhale en bronne vra om spesiale aandag, en dit konstitueer die eerste en belangrikste rede vir historiese navorsing oor Jesus van Nasaret

\subsection{Waaroor handel historiese Jesus navorsing in hierdie benadering?}

Met bogenoemde argument is reeds die terrein betree van waaroor historiese Jesus navorsing dan handel. Ook hier kan van vernuwing gepraat word.

Die uitgangspunt van hierdie benadering is dat daar nie vasgestel kan word watse soort figuur Jesus was deur die historiese persoon te probeer skei van die vroeë kerk se weergawes nie, maar deur die figuur in die weergawes te vind. Die aanname is dat die historiese figuur nie gekonstrueer kan word aan die hand van outentieke materiaal nie, maar deur middel van 'n analise van die sosiale figuur binne die kulturele konteks. Dit beteken dat die verhale oor hom, die soort verhale wat vertel is, die soort sosiale figuur wat hy was, alles binne 'n kulturele en historiese konteks begryplik gemaak moet word. Die hooftak is nie om dit wat outentiek is te identifiseer nie, maar om die gegewens binne 'n kulturele konteks te interpreteer deur te vra oor watse soort figuur is die verhale vertel wat aan Jesus toegeskryf word. Dus, die geskiedenisbeskouing is nie positiwisties nie, maar interpretatief, en die basis is nie outentieke materiaal nie, maar 'n outentieke beeld van Jesus as historiese figuur.

Hiermee is reeds gesê dat die fokus in hierdie benadering nie val op die biografiese elemente, of op wat Jesus sou gesê of gedoen het nie 
(laasgenoemde twee aspekte kan in elk geval eers verstaan word nadat die kulturele sisteem in ag geneem is). Hierdie aspekte kan inderdaad ter sprake kom, maar sal afhang van beide die kulturele sisteem en die soort figuur wat Jesus was. Sekere soort figure in spesifieke kulturele sisteme genereer kenmerkende soort verhale en biografiese elemente. Dit kan beoordeel word nadat die dinamika van die soort figuur, asook die tradisieprosesse wat sulke persone omring, in ag geneem is.

Histories-antropologiese studies oor godsdienstige figure in talle kulture wys dat daar niks nuuts is aan die vertel van spesiale geboortes, beheer van natuurelemente, geesbesetenheid, ervaring van visioene en gesigte, genesing en eksorsismes en dies meer nie. Die uitdaging om Jesus as historiese figuur te beskryf, is om 'n soort sosiale figuur te identifiseer wat in die kulturele konteks pas en oor wie die verskeidenheid verhale vertel word wat aan Jesus toegeskryf word. Met ander woorde, wat nodig is, is 'n sosiale analise van die soort figuur en die kulturele konteks waarbinne hy opgetree het.

Myns insiens sal vernuwing in historiese Jesus navorsing plaasvind wanneer die bestaande pogings om Jesus as sosiale figuur te beskryf meer suksesvol is in die hantering van beide die verskeidenheid tradisies oor hom (beide die genesings, eksorsismes, onderrig, profesieë, wonders, ens) en die begronding van daardie soort figuur en aktiwiteite in die spesifieke kulturele konteks van die eerste-eeuse Mediterreense wêreld. Sonder begronding in die kulturele konteks kan daar nie betekenisvol oor 'n historiese figuur gepraat word nie. Met ander woorde, as historiese figuur in sy tyd was Jesus nie 'n "gewone" mens aan wie later allerhande mites toegeskryf is nie, en ook nie 'n soort superwese nie, maar ' $n$ figuur wat in sy tyd opgetree en so deur sy tydgenote erken is. In so ' $n$ benadering is die beskrywing van die soort figuur wat Jesus in sy konteks was nie maar bloot 'n etiket wat op die eindproduk van geïdentifiseerde outentieke materiaal geplak word nie.

Vervolgens kan enkele lyne getrek word van 'n vernuwende benadering tot Jesus as historiese figuur.

\subsection{Uitgangspunte van ' $n$ kultuur-sensitiewe benadering}

As na meer spesifieke uitgangspunte gekyk word, is die eerste dat die bronne waarskynlik nie in lae oorgelewer is soos die Jesus Seminaar ons wil laat glo nie; ten minste nie soos deur die argeologiese metafoor voorgestel word nie: oorspronklike outentieke brokkies wat deur die vroeë kerk omvorm is tot lae en lae mitologiese en teologiese verhale.

Hierdie argument kan met een voorbeeld gedemonstreer word. Crossan (sien 1995:1-6) verduidelik die verskil tussen homself en een van die prominente figure in die tradisionele benadering, Raymond Brown. Hoewel alle navorsers erken dat nie alles in die evangelies outentiek is nie, kan die verskille beskryf word met ' $n 20-80$ verhouding. Vir Crossan is $20 \%$ outentiek en $80 \%$ nie-outentiek en by die New Quest is dit net omgekeerd $(80 \%-20 \%)$. In beide gevalle word 'n stratifikasie van die materiaal aanvaar. ' $n$ Transformasie van hierdie uitgangspunt is nie om van ' $n$ 50-50 of enige ander verhouding te praat nie, maar om af te stap van die idee dat daar hoegenaamd outentieke en nie-outentieke materiaal op die manier saamgevoeg is. Dit is soos om in die natuur versus kultuur debat te probeer vra watter bydrae tot gedrag is natuur en watter is kultuur. Die vraag is net nie sinvol nie; die komplekse prosesse moet eerder beskryf word. Dieselfde geld hierdie aspek van Jesus navorsing.

Myns insiens is 'n tweede uitgangspunt, naamlik dat die onderskeid tussen Christus as mitologiese figuur en Jesus as historiese persoon (veral 'n leraar vry van mitologiese elemente) nie net 'n oordrywing van 'n werklike probleem nie, maar ook 'n anakronistiese beskrywing van Jesus as historiese figuur, en dat dit die tekens van 'n apologetiese truuk dra (sien Smith 1978:3-5). Dit is anakronisties omdat daardie onderskeid nie in die eerste eeu gemaak kan word nie, en omdat dit wat aan die sogenaamde verkondigde Christus toegeskryf word, in daardie wêreld inderdaad aan 'n historiese persoon toegedig kon word. 'n Kultuur-sensitiewe lees van die bronne sal juis bevestig dat talle elemente wat as onhistories beskou word in hierdie onderskeid, juis tot die biografie van 'n historiese persoon in daardie kulturele sisteem kon behoort. Die aanname is dat dit meer waarskynlik is dat iemand se volgelinge die aard en styl van aktiwiteite en gebruike van die groep sal kontinueer as om totaal nuwes te skep na die leier se dood. Dit is, met ander woorde, meer logies dat die dissipels die gebruike en praktyke wat hulle met Jesus gedeel het, sou kontinueer na sy dood as om skielik totaal nuwes te skep. Daarom, indien die woorde en dade wat aan Jesus toegeskryf word, in sy eie leeftyd verstaan kan word, is dit onnodig om dit as skeppinge van die vroeë kerk te beskou. Die oordrewe onderskeid tussen die historiese Jesus en die verkondigde Christus hoef dus nie aanvaar te word nie.

'n Derde uitgangspunt is dat daar in talle kulture voorbeelde van spesifieke soort figure is aan wie die tipe verhale en eienskappe toegeskryf word wat ons in die evangelies vind. Figure met spesiale geboortes en die vermoëns van genesing, geestesvervulling, ensovoorts wat deel is van die figuur se biografie. Nadat die verhale en tradisies binne die kulturele raamwerk van die tyd geïnterpreteer is, mag dit wees dat daar elemente is wat nie inpas in daardie raamwerk nie en toegeskryf kan word aan die latere tydperk in die vroeë kerk se lewe. Dit mag ook wees dat daar mitologiese elemente ingesluip het, maar dit kan alleen bepaal word nadat Jesus as historiese figuur beskryf is met behulp van ' $n$ toepaslike model. So 'n toepaslike model, is gesê, is een wat al die tradisies kan 
hanteer en in die kulturele konteks pas. Hierdie onderskeid beskryf dus eerder 'n suiweringsproses aan die einde as 'n vertrekpunt.

'n Volgende uitgangspunt is dat daar ' $n$ verband is tussen die soort verhale wat oor 'n persoon vertel word, die persoon as sosiale figuur, en die konteks waarbinne 'n persoon leef. Indien sodanige verband in die tradisies en konstruksie van Jesus aangetoon kan word, is dit weereens onnodig om groot dele van die tradisies oor hom aan die kreatiewe aktiwiteite van die vroeë kerk toe te skryf.

Daar word eenvoudig in historiese Jesus navorsing (veral deur lede van die Jesus Seminaar) te maklik beweer dat 200 jaar se navorsing oor die bronne nie sondermeer ongedaan gemaak kan word nie (sien byvoorbeeld Crossan 1998:97; Borg 1999b:236). Indien daardie navorsing op 'n dwaalspoor is, kan dit nie net nie, maar behoort dit ook ongedaan gemaak te word. Soos reeds uitgewys, moet daar nie vergeet word nie dat hierdie tradisie van navorsing dat die evangelies eintlik uit verskillende lae bestaan - lae wat van Jesus self af kom en lae wat deur die vroeë kerk toegevoeg is, hand aan hand ontwikkel het met die positiwistiese onderskeid tussen ' $n$ historiese en mitologiese figuur. As hierdie onderskeid nie meer gehandhaaf kan word nie, waarom die ander een?

Hierdie is nie die plek om al die teenargumente volledig te bespreek nie. Dit is voldoende om te sê dat op grond van die aard van die ontstaan en oorlewering van die Jesus verhale en tradisies (dit het berus op menslike geheue en is oorgelewer deur middel van gerugte en vertellinge), daar waarskynlik geen oorspronklike woorde van Jesus behoue gebly het nie (sien byvoorbeeld Botha 1993; 1998). Die uitdaging vorentoe is om op 'n nie-positiwistiese manier ('n benadering wat nie bloot op outentieke materiaal gebou is) oor Jesus as historiese figuur te praat. Dit beteken nie dat niks oor Jesus as historiese figuur gesê kan word nie. Aan die hand van bogenoemde aannames is dit moontlik om op 'n heel nuwe en vernuwende manier met die vraag na Jesus as historiese persoon om te gaan. Enkele van die implikasies sal kortliks bespreek word.

\subsection{Enkele implikasies van ' $n$ kultuur-sensitiewe benadering}

Binne hierdie benadering word daar op ' $n$ ander manier met die meeste aspekte van Jesus as historiese figuur en met die verskillende aspekte in die navorsing omgegaan.

'n Kultuur-sensitiewe benadering fokus op andersoortige biografiese inligting - die soort wat nie gewoonlik met geboorte- en doodsertifikate geverifieer kan word nie. Met ander woorde, dit fokus nie op "het dit gebeur" nie, of "is dit waar nie", maar op "wat word vertel het gebeur" en dit wat wys die gegewens was deel van die figuur se biografie. Laasgenoemde insig is belangrik. Terwyl die positiwistiese geskiedskrywing soek na "het dit gebeur?" is die vraag hier eerder, "was dit deel van iemand se biografie?" So kan die aanspraak en die vertelling oor 'n spesiale geboorte deel van iemand se biografie wees (mense vertel dit oor die persoon as hulle dorpie besoek word, of as oor die figuur gepraat word, of wanneer hulle die figuur raakloop, tree hulle op 'n sekere manier op) sonder dat daar enige aanspraak oor die geboorte self gemaak hoef te word. As mense op 'n spesifieke manier omgaan en 'n figuur op spesiale maniere behandel omdat daar 'n aanspraak van 'n spesiale geboorte is, is hierdie optrede en behandeling deel van die figuur se biografie sonder dat enige iets oor die geboorteproses self gesê hoef te word. In kort, iets is nie net deel van Jesus se biografie indien vasgestel kan word dat dit "werklik" gebeur het nie, maar ook indien verhale daaroor waarskynlik oor die figuur gesirkuleer het. Die vraag bly natuurlik of hulle ook gedink het dat dit wat hulle vertel het werklik gebeur het. Hieroor enkele opmerkings later.

Ten opsigte van Jesus se biografie stel die positiwistiese geskiedskrywing vrae wat vanuit hierdie benadering óf nie beantwoord kan word nie óf waarop die antwoord moet wees, "ons weet eenvoudig nie". Neem as voorbeeld een van die aspekte uit die geboorteverhale wat vroeër reeds genoem is (sien $\S 2.1$ ). Waar is Jesus gebore, in Bethlehem of in Nasaret? Nadat gekyk is na die pogings van positiwistiese geskiedskrywing, wat deesdae al meer na Nasaret wys, is dit waarskynlik beter is om te sê, dit is nie moontlik om die vraag te beantwoord nie.

Wat kan egter histories van die verhale gemaak word? Dit is moontlik dat beide die maagdelike geboorte verhaal asook die storie oor die Dawidiese afkoms uit Bethlehem reeds in Jesus se leeftyd oor hom vertel Dawidiese afkoms uit Bethlehem reeds in sesu "biografie" (lewensloop) gewees het indien hy tot die kategorie mense behoort het oor wie die soort verhale vertel is. Nie net inligting oor die aard van sy geboorte nie, maar ook oor die impak van die verhale van 'n spesiale geboorte op sy lewe, kan vir ons iets sê oor sy persoon. Op die manier is inderdaad biografiese inligting van 'n ander aard (eie aan die kulturele sisteem van die tyd) bekom. Ons mag miskien nie presies weet waar Jesus gebore is of wat sy ma se fisiese toestand was met sy geboorte nie, maar ons kan iets anders van sy biografie weet: wanneer hy 'n dorpie besoek het, het die mense waarskynlik vir mekaar vertel: het jy gehoor, hierdie man het 'n maagdelike geboorte gehad. Omdat hierdie stories oor Jesus rondgegaan het, het mense op 'n sekere manier opgetree, en het waarskynlik ander soortgelyke verhale oor hom ontstaan wat kon bydra tot sy selfbeeld en optrede teenoor hulle. Hierdie soort verhale word nie na mense se lewens optrede teenoor hulle. Hierdie soort verhale word hulle lewensloop omdat dit in hulle lewe vertel word. Die "werklike" figuur was nie soos wat die Jesus Seminaar vir ons wil laat glo, 'n "gewone" persoon wat met mitologiese of christologiese oortreksels beklee is nie, maar kon (indien hy

ISSN 1609-9982 = VERBUM ET ECCLESIA Jrg 22 (1) 2001 
tot 'n sekere kategorie persone behoort het in sy samelewing) reeds met hierdie verhale saamgeleef het.

Die verhale oor Jesus se maagdelike geboorte stem ooreen met talle ander verhale oor spesiale geboortes (beide in daardie werreld en in talle ander kulture - selfs vandag). Daar is niks unieks aan nie, want die aanspraak oor spesiale geboortes is deel van 'n stel kulturele kodes. Het daardie mense gedink dat in die geval van Jesus sy ma 'n maagd was met sy konsepsie, en dat die gees van God daarvoor verantwoordelik was? Waarskynlik, want hulle het gedink dat die gode veel meer as dit in mense se lewens verrig. Beteken dit dat ons oor die ginekologiese toestand van sy ma enige iets kan weet? Nee, waarskynlik nie. In die wêreldbeeld van biologiese sisteme van lewe, is die swanger word van 'n maagd moontlik deur invitro bevrugting of kunsmatige inseminasie. Sonder 'n sperm van 'n man kan 'n vrou nie swanger word nie. Punt. Hier lê die uitdaging - om beide wêreldbeelde ernstig op te neem en tot dialoog te bring.

Die interpretatiewe inslag van hierdie benadering kan ook in ' $\mathrm{n}$ kort beskrywing saamgevat word.

Jesus het in 'n wêreldbeeld opgetree waarin anders oor die wêreld en die werklikheid geoordeel is. Op grond van die meeste verhale is dit onmoontlik om te sê of die verhaal hoegenaamd iets te sê het vir die vrae wat ons normaalweg vra ("het dit só gebeur?"). Die eerste vraag is: wat word in daardie kulturele sisteem vertel, en die tweede vraag is: hoe kan dit na 'n ander kulturele sisteem toe vertaal word. Hierdie proses sal waarskynlik dikwels beteken dat die vergelyking niks meer as ' $\mathrm{n}$ uitstalling van kontraste is nie.

Tot ' $n$ mindere of meerdere mate is elemente van hierdie benadering reeds 'n geruime tyd in omloop. Mens dink aan die grootliks geïgnoreerde studie van Smith (sien 1978) en die onlangse werk van Davies (sien 1995). My eie navorsing staan in hierdie lyn (sien Craffert 1999).

\section{SLOTOPMERKINGS}

Historiese Jesus navorsing kan op verskillende maniere aangepak word.

Die Jesus Seminaar gaan uit van outentieke woorde en histories vasstelbare dade van Jesus en konkludeer dan wie en watse soort persoon hy was. Met die filosofiese en wêreldbeeld keuses van hierdie benadering kan dit nie anders as om die historiese persoon te onderskei van die mitologiese verkondigde Christus, en laasgenoemde as mitologie af te maak nie.

Die tradisionele benaderinge van die New Quest aanvaar dat die sinoptiese beeld grootliks betroubaar is, maar net gesuiwer moet word van kleiner onhistoriese elemente wat ingesluip het. Diegene wat saam met die meerderheid navorsers hul positiwistiese wêreldbeeld wil aanvul met bonatuurlike elemente, kan nie anders as om Jesus van Nasaret en die verhale oor hom te onthistoriseer nie. So 'n onderskeid het in daardie wêreld nie bestaan nie.

Vernuwing in historiese Jesus navorsing beteken, myns insiens, dat beide hierdie benaderinge verruil word vir ' $n$ kultuur-sensitiewe benadering. Dit vra ander vrae en kan die meeste van die bestaande vrae nie bevredigend antwoord nie. Wat dit wel kan doen is om respek te toon vir die kulturele sisteem en die historiese figuur van Jesus van Nasaret wat verskil van dié van moderne mense. Terwyl die eie moderne wêreldbeeld gehandhaaf word, word 'n proses van kruis-kulturele interpretasie in werking gestel wat bemiddel tussen vertelling in daardie wêreldbeeld en die interpreteerder se wêreldbeeld.

Die aanspraak dat daar geen eenstemmigheid bestaan oor waarom, waaroor en hoe historiese Jesus navorsing gedoen word en gedoen behoort te word nie, moet nie ligtelik opgeneem word nie. Konkreet beteken dit dat daar 'n onderlinge band is tussen die hoe, die waarom en die waaroor dit handel. Hoe dit gedoen word, bepaal waarom en waaroor, en waarom bepaal hoe en waaroor. Vernuwing beteken dus dat selfs die redes waarom historiese Jesus navorsing gedoen word en waaroor dit handel, verander word. As die hoe verander word, verander ook die waaroor en die waarom.

Die moontlikhede wat hierdie vernuwing open, is legio - veral in die Afrika konteks. Dit is "legio" vir diegene wat wil vashou aan die oorgelewerde benaderinge omdat dit onversoenbaar is met daardie waarom, waaroor en hoe vrae. Vanuit die moderne wêreldbeeld wat in daardie benaderinge gebruik word, is uitwerping van hierdie soort verandering een moontlikheid. Maar die moontlikhede is ook "legio" in die sin dat die Afrika konteks menige parallelle bied om insig te verkry in sulke sosiale figure, die dinamika van die vertellinge oor hulle, en die soort wêreldbeeld waarbinne die evangeliestof betekenis het. Die uitdaging is om hierdie insigte aan te wend om oor Jesus as historiese figuur in sy eie konteks te praat op 'n manier dat hy tereg kom in sy eie konteks en ook toeganklik is vir diegene wat vanuit 'n ander kulturele sisteem en wêreldbeeld situasie kom. Daarmee word nie bedoel dat dit toeganklik is soos in direk oordraagbaar nie, maar op so ' $n$ manier dat beide wêreldbeelde gerespekteer word en dialoog moontlik word.

\section{Literatuurverwysings}

Allison, D C 1998. Jesus of Nazareth: Millenarian prophet. Minneapolis: Fortress. Blomberg, C L 1995. Where do we start studying Jesus? in Wilkins \& Moreland 1995: 17-50.

ISSN 1609-9982 = VERBUM ET ECCLESIA Jrg 22 (1) 2001 
Borg, M J 1987. Jesus a new vision: Spirit, culture, and the life of discipleship. San Francisco: Harper \& Row.

Borg, M J 1994. Jesus and eschatology: Current reflections, in Jesus in contemporary scholarship, 69-96. Valley Forge: Trinity.

Borg, M J 1999a. Seeing Jesus: Sources, lenses, and method, in Borg \& Wright 1999: 1-14.

Borg, M J 1999b. A vision of the Christian life, in Borg \& Wright 1999: 229-250.

Borg, M J \& Wright, N T 1999. The meaning of Jesus: Two visions. San Francisco: Harper.

Botha, P J J 1993. The social dynamics of the early transmission of the Jesus tradition. Neotestamentica 27(2), 205-231.

Botha, P J J 1998. Rethinking the oral-written divide in gospel criticism: The Jesus traditions in the light of gossip research. Voices: A Journal for Oral Studies 1, 28-58.

Brown, R E 1973. The virginal conception and bodily resurrection of Jesus. New York: Paulist Press.

Casey, P M 1998. Where Wright is wrong: A critical review of N.T. Wright's Jesus and the victory of God. JSNT 69, 95-103.

Craffert, P F 1999. Jesus and the shamanic complex: First steps in utilising a social type model. Neot 33(2), 321-342.

Craig, W L 1995. Did Jesus rise from the dead? in Wilkins \& Moreland 1995: 141 176.

Crossan, J D 1991a. The historical Jesus: The life of a Mediterranean Jewish peasant. San Francisco: Harper.

Crossan, J D 1991b. The life of a Mediterranean Jewish peasant. The Christian Century Desember, 18-25, 1194-1200.

Crossan, J D 1994. Jesus: A revolutionary biography. San Francisco: Harper.

Crossan, J D 1995. Who killed Jesus? Exposing the roots of anti-Semitism in the gospel story of the death of Jesus. San Francisco: Harper.

Crossan, J D 1998. The birth of Christianity: Discovering what happened in the years immediately after the execution of Jesus. San Francisco: Harper.

Davies, S L 1995. Jesus the healer: Possession, trance, and the origins of Christianity. London: SCM.

Du Plessis, I J 1985. Nasaret of Egipte: Wie is reg? Historiese perspektief op die Nuwe Testament. Pretoria. Van Schaik.

$\mathrm{Du}$ Toit, A B 1980. Die historiese Jesus en die verkondigde Christus van die evangelies, in Handleiding by die Nuwe Testament IV: Die sinoptiese evangelies en Handelinge: Inleiding en teologie, 255-281. Pretoria: NG Kerkboekhandel.

Du Toit, A B 1997. Foreword, in Du Toit, C W (ed), Images of Jesus, xi-xiv. Pretoria: Unisa.

Freyne, S 1997. Galilean questions to Crossan's Mediterranean Jesus, in Arnal, W E \& Desjardins, M (eds) Whose historical Jesus?, 63-91. Waterloo: Wilfred Laurier University Press.

Funk, R W 1996. Honest to Jesus: Jesus for a new millennium. San Francisco: Harper.

Funk, R W \& The Jesus Seminaar 1998. The acts of Jesus: The search for the authentic deeds of Jesus. San Francisco: Harper.

Funk, R W, Hoover, R W \& The Jesus Seminar 1993. The five gospels: The search for the authentic words of Jesus. New York: Macmillan.
Habermas, G. R. 1995. Did Jesus perform miracles? in Wilkins \& Moreland 1995: 117-140.

Johnson, L T 1996. The real Jesus: The misguided quest for the historical Jesus and the truth of the traditional gospels. San Francisco: Harper.

Kelber, W H 1994. Jesus and tradition: Words in time, words in space. Semeia 65, 139-167.

Lüdemann, G 1998. The great deception and what Jesus really said and did. London: SCM.

Marsh, C 1998. Theological history: N.T. Wright's Jesus and the victory of God. JSNT 69, 77-94.

Meier, J P 1990. The historical Jesus: Rethinking some concepts. TS 51, 3-24.

Meier, J P 1991. A marginal Jew: Rethinking the historical Jesus, Vol 1: The roots of the problem and the person. New York: Doubleday.

Miller, R J 1998. History is not optional: A response to 'The real Jesus' by Luke Timothy Johnson. BTB 21(1), 27-34.

Moxnes, $\mathrm{H}$ 1998. The historical Jesus: From master narrative to cultural context. BTB 28(4), 135-149.

O'Collins, G 1997. The resurrection: The state of the questions, in Davis, S T, Kendall, D \& O'Collins, G (eds), The resurrection: An interdisciplinary symposium on the resurrection of Jesus, 5-28. Oxford: Oxford University Press.

Saler, B 1977. Supernatural as a Western category. Ethos 5, 31-53.

Sanders, E P 1985. Jesus and Judaism. London: SCM.

Sanders, E P 1992. Judaism: Practices and belief 63 BCE - 66CE. London: SCM.

Sanders, E P 1993. The historical figure of Jesus. London: Penguin.

Smith, M 1978. Jesus the magician. London: Victor Gollancz.

Theissen, G \& Merz, A 1998. The historical Jesus: A comprehensive guide. London: SCM.

Van Aarde, A 2000. Die relevansie van die historiese Jesus-ondersoek vir kerklike teologie. HTS 56(2\&3), 549-571.

Wilkins, M J \& Moreland, J P 1995. Introduction: The furor surrounding Jesus, in Wilkins \& Moreland 1995: 1-15.

Wilkins, M J \& Moreland, J P (eds) 1995. Jesus under fire. Grand Rapids: Zondervan.

Wright, N T 1992. Quest for the historical Jesus. ABD 3, 796-802.

Wright, N T 1999a. Born of a virgin? in Borg \& Wright 1999: 171-178.

Wright, N T 1999b. Knowing Jesus: Faith and history, in Borg \& Wright 1999:1527.

Wright, N T 1999c. The transforming reality of the bodily resurrection. in Borg \& Wright 1999: 111-127. 